\title{
ANALYSIS OF A LAYOUT SOLUTION OF DESIGN BY CTU STUDENTS - ÚŠTĚK RECTORY
}

\author{
Helena Hexnerová \\ Czech Technical University in Prague, Faculty of Civil Engineering, Department of \\ Architecture, Prague, Thákurova 7, Czech Republic; helena.hexnerova@fsv.cvut.cz
}

\begin{abstract}
The main objective of this paper is to compare student projects of café and restaurant interior in the preserved building of the rectory in a monument reservation in the centre of the town Úštěk. There are six projects dealing with suitability of café and restaurant in the building of the rectory. Students designed interiors and they also worked on the layout of the building with the adjacent courtyard and farm buildings, including their modifications. The article analyses and compares individual student works in terms of the use of areas for individual functions of operation and the number of seats for guests.
\end{abstract}

\section{KEYWORDS}

Rectory, Layout, Restaurant design, Comparative analyses

\section{INTRODUCTION}

This article deals with an analyses of student projects of layout solution of the building of the rectory in Úštěk and its use as a café and restaurant. The projects were done in cooperation with Úštěk town hall and Department of Architecture at CTU. Students should have designed interiors of the café and restaurant with kitchen in the former rectory building situated on the square in town Úštěk. The work was commissioned in 2019 in two subjects focused on interior design. First subject was an optional XIND, which is intended for fifth-year students of the Faculty of Civil Engineering in the field of Architecture and Civil Engineering. Second subject was INTERIOR - a part of the Erasmus program. There were two students from Bulgaria and one from Croatia within the Erasmus program who worked separately and five Czech students who worked in pairs and one student worked alone.

Úštěk is a town which was almost untouched by tourism until recent years. It was popular among film makers thanks to its genius loci. In recent years the seasonal attendance of Úštěk has begun to increase thanks to cultural events organized in cooperation with the townhall and as well as thanks to the entrepreneurship of citizens and the developing cycling. Due to the increased number of visitors, there was an acute shortage of urban amenities. In cooperation with the city council, teachers of the subjects mentioned above made a task for students to create a plan of the restaurant and the café in the building of the former rectory.

\section{Initial assumptions}

Students' plans of the café and restaurant layout were evaluated by the method of analyses, compared and analysed. There were six plans and they were named as students' numbers 1-6. For all designs there were calculated: the total used areas, the areas of demolished structures projected into the layout of the areas of individual operations, the number of seats for guests and all of these were compared with each other to verify the operation.

The plans were also used as a background for the negotiation about the restaurant and café in the building with the monument care authority. 


\section{Goals of the work}

The goal of the student works was to prove the possibilities of placing the restaurant and café into the building of the former rectory in Úštěk. It was necessary to check the capacity of the object during the winter as well as the summer opening and to design the possible ways of the layout. Second aim was to get the inspiration how to do the reconstruction of the building. The works should have shown the creativity in the ways how to use the object of the rectory without any limited factors. The final projects should have been used for the negotiation with the monument care office.

This article analyses and compares individual student works in terms of the use of space and number of seats for the guests of the restaurant.

\section{Assignment of student works}

The assignment was as follows: The content of the project is to design an interior of the restaurant/ café in the protected object of the former rectory, which is situated on the square next to the late Baroque church of St. Peter and Paul in Úštěk. Kitchen, restaurant with the bar counter, background and summer terrace should be on the ground floor. On the first floor there should be a multi-purpose hall for weddings, birthday celebrations etc. There are six rooms on the ground floor and a hall. Two rooms should have been used as a kitchen. The entrance to the building is not barrier-free.

\section{Student works}

The students had a lot of freedom in preparing the design. In addition to interior design, they also worked out the layout solution, including its modifications. There was still a chapel in operation during the research and the rectory made a request to the townhall not to place a bar to this part. The townhall gave this project also to the design company as well as to the students. This request was not binding for the students because the projects of the students should bring the investor as much inspiration as possible. The basis for the work was the construction focus of the rectory and photographic documentation, which students acquired during a visit to the city and a survey of the building.

\section{INTRODUCTION TO THE TOPIC}

The Czech Republic has a long history of heritage protection, but the scope and extent of the reconstruction - conservation are an issue. Worldwide, we can find places where are doubts whether to protect and reconstruct the historical buildings. The reasons are historical and also poor durability of building structures. However, even there, over the last fifty years, the approach to preserving immovable monuments has changed [1]. In the interests of conservation, it is always necessary to find a balance and take advantage of the inclusion of three basic sectors, public, private and civic, as discussed in the research of the Getty Institute. This research also describes criteria and three levels for successful sectoral cooperation. The Czech Republic is in the level "one" which is the lowest of the levels [2].

The way how to use historical buildings is a topic which is crucial for monument restoration. Researches from all over the world deal with the method of finding new content for a protected building, with the help of various methodologies, as the extent and manner of preserving the heritage is a global issue and problem. Reconstruction and use of sacral buildings is a separate chapter [7, 8].

Due to the Australian research it is necessary to take into account following criteria for the final design of reconstructed building: physical, political, legal, social, economic, technological and functional [9]. Foster [10] studies economic criteria of reconstruction and use of the monuments. 


\section{History of town Úštěk}

Úštěk, a picturesque historical town on a promontory, which is also a monument reserve, was first mentioned in 1361, when it was held by Petr z Michalovic who held also the surrounding estate, but it was probably founded in the second half of the $13^{\text {th }}$ century. The name Úštěk as well as Ouštěk was used in the $19^{\text {th }}$ century, till 1945 it was called Auscha. This name was used especially by German part of inhabitants [11].

There were also found remains of the pottery and late Slavic burial ground from the turn of the $9^{\text {th }}$ and $10^{\text {th }}$ centuries [12].

The urbanism of the town was set by the high sandstone promontory above the confluence of the streams where was the town placed. There was an important road going through the town that led from Litoměřice via Česká Lípa to Lausitz. The first strategically located settlement with a fortress was set up on the hill. Northern and southern side made a natural barrier for the town. The fortress was lately replaced by the independently fortified castle, which was the centre of the southern part. Thanks to the shape of the narrow promontory, a slightly curved street square was created, which widened in a funnel-like direction towards the center. The town was without developed street network. The burgher houses had narrow deep plots, around the perimeter of the square, with multi-storey cellars carved into sandstone. In some of them there were exit corridors. The burgher houses were often rebuilt in the late Gothic period, their character was still preserved. These were one-storey (two-storey) houses, on the ground floor with a stone farm arcade, on the two to four-axis floor. The ridge of the roofs was perpendicular to the square, the gable was steep and high[13]. Upper floors of the houses were made of wood, the roof was covered by shingle. Significant building modifications took place mainly after fires [11].

In $14^{\text {th }}$ century the inner town and the church of Saint Michael with the cemetery were built. In the second half of the $14^{\text {th }}$ century, the city was surrounded by walls with two small and two big gates. Western one called Litoměřická or Česká, eastern one called Leipzig or German, prevented the entry of carriages into the city. There were two smaller gates in the north and south. The southern one was called Roudnická. The Renaissance period meant a time of development for Úštěk. Most of the buildings, including the town gates, were rebuilt. The development of the city was also on the suburbs. The town hall was built and the castle palace was rebuilt. The town was confiscated in 1621 and handed over to Jesuits.

They built many important baroque buildings. In the 20 s of the $17^{\text {th }}$ century the brewery was also rebuilt. After the Jesuits were abolished the town was passed into hands of townspeople. They built a new school and also a courthouse. Many buildings were rebuilt due to two big fires in 1856 and 1859. In some places there is also a merging of plots, in the case of houses the ridge of roofs is parallel to the facade. This partially disrupts the order of the Gothic order of the houses. Part of the arcades were changed and used for shops. The town gates were demolished not to narrow the street profile, the gate called Litoměřická was destroyed in 1830, Lipská gate in 1859. In the second half of the 19th century, a residential colony of "ptači domky" (bird houses) was built in Kamenná Street. In 1888 a railway connection was built to Velké Březno, in 1898 followed the railway from Litoměřice via Úštěk to Česká Lípa. At the turn of the $19^{\text {th }}$ and $20^{\text {th }}$ centuries, industrial enterprises were established, and gradually also new quarters of family villas. A pond called Chmelař was renewed [13], [14].

\section{History and description of the rectory (Deanery No. 1)}

One of the rectory buildings was firstly mentioned in the first half of the $16^{\text {th }}$ century. It was situated on the Mírové square. Nowadays, there is a house number 67 . The original building was one storey wooden house with two rooms, a cowshed, shed and a yard. A town paid its reconstruction in 1567 and a stable was added. In 1626 it was demolished and replaced by a new rectory and in 1628 a new barn was built. The building had been used till 1722 when a new rectory was built. There was no longer a suitable place for it by the city walls [11]. Church dedicated to St. Michal, dated to 1363 - 1756, was the first parish church with the original cemetery [13]. The 


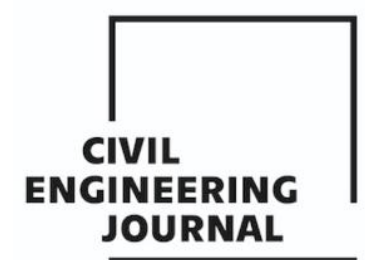

Article no. 45

THE CIVIL ENGINEERING JOURNAL 3-2021

cemetery by the St. Michal church was closed in 1721 and it was moved to the new place close to the Church of the Holy Trinity (1668) [11]. This created a place where a new baroque building of the current rectory was built in the years 1720-1722 at the expense of the Jesuits of Liběšice. The new rectory was built into the square in terms of floor plan [14]. The rectory building was already made of bricks, the roofing was made with shingles. It was bought from the Liběšice nobility in 1725 by the City Hall [11]. The baroque building is situated on the Mírové square. It is situated opposite the church of Saint Peter and Paul, which was built after the demolition of the Church of St. Michal, in the years 1764-1972. The rectory stands also next to the castle. The two-storey building, symmetrically designed, with seven window axes and a three-axis central risalit, which is decorated with rustic in the corners, as well as both wings, was built in 1722 . It is probably the work of the Litoměřice builder of Italian origin Octávio Broggio [13].

The rectory is a two-storey, partly basement, building with a hipped roof, with seven window axes towards the square. It has central corridor, a hall with stairs and entrance to the yard. The sanitary facilities are accessible from the hall too. Most of the rooms are accessible from the hall and you can go through one to another. Most of them have a vaulted ceiling. Upstairs there are rooms with stucco decoration. At the time of the survey, the ground floor of the rectory was used for occasional exhibitions, the chapel and its parish lobby and the first floor were rented by amateur actors. The basement as well as the attic were not used. The rectory building also has other related, original economic parts that are connected to the courtyard. The courtyard is accessible not only through the rectory building, but it also has a generous entrance through the original gate. The rectory was reconstructed in 2006.

Nowadays the rectory is owned by the town Úštěk. On the first floor there is a background for a group of amateur theatre actors called Pik-art. There was created also a place for meeting of pensioners, but it was not used [15].

\section{Rectory from the point of view of the monument care}

Cultural monuments register no. ÚSKP 42650/5-1902 - deanery, protected monument since 3. 5. 1958. Area monument protection - monument reservation register no. ÚSKP $1039-$ Úštek protected since 1. 10. 1980.

\section{STUDENT WORKS}

\section{Layout solution}

Students have chosen different layout solutions. Mostly they interfere to the layout by the demolishing some walls or by opening vistas and passages in the load-bearing walls. The bar was mostly situated in the central widened corridor, once it was in the staircase hall and once in the chapel. The chapel and the farm building adjacent to the parish were most often used for the kitchen. In one case, the kitchen was located on the left side of the rectory.

Student No. 1 used the staircase hall for the bar. Kitchen and tasting room are in the left. The corridor widened by the demolishing of the walls and former chapel are designed as a dining room. Toilets are situated in the space behind the stairs. The outdoor part, adjacent to the rectory, is used as a summer dining room. Opposite farm house in the yard are designed as a warehouse and toilet for summer operation, when the yard is designed for summer seating Figure 1.

Student No. 2 placed the kitchen into the chapel and summer kitchen to the adjacent farming spaces. Bar is placed in the entrance part created by the widening of the corridor. Toilet is situated behind the staircase, other space is used as a dining room. The yard is used for sitting in the summer. Outdoor farming building is used as a warehouse and a toilet Figure 2.

Student No. 3 places the bar into the central entrance space. It makes a dominant part of all space. The kitchen is located to the adjoining outdoor annex which is connected to the hall with the staircase by the corridor. Other space is gently used as a dining space, toilet for disabled people 


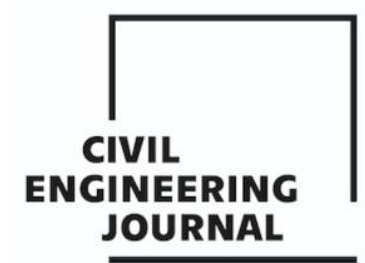

Article no. 45

THE CIVIL ENGINEERING JOURNAL 3-2021

and guests is situated behind the staircase. Next toilet, souvenir shop and the storage are placed in the farm house.

Students No. 4, who worked in a pair, made a setup which makes maximum use of the space that was available. The main consideration of the design is the axiality of the building with a view across the entire building, where is also situated a bar in the entrance extended part. They placed the kitchen to the chapel. The kitchen has access to a warehouse and facilities for employees, as well as an outdoor bar and kitchen in the adjoining farm building. Other rooms are used for sitting. The supply is solved by a new entrance to the square. In the basement there are bathrooms, warehouses and a bar. The yard is used for sitting in the summer, the toilet is in the opposite farm building. There is also a multi-purpose hall and upstairs there is a simple accommodation for eight people. Part of the yard is covered by vegetation and there is also a sandpit with live wicker shading. The courtyard also maintains a connection with the castle courtyard Figure 4.

Student No. 5 placed a bar to the widened central corridor. The bar is followed by box seating and in the left part of the layout there are lounges. Kitchen is situated in the former chapel and outdoor kitchen is in the adjacent farm building. Toilet is behind the staircase. Supply is solved via the corridor which was made by breaking down the entrance from the square in the right part of the building. The yard is used for summer sitting. In the farm house there is a background for the summer terrace, toilet, storage for furniture a multi - purpose space Figure 5.

Students No. 6, who worked in a pair, situated the bar into the chapel. Kitchen is in the adjacent farmhouse. Main building is mainly used as a dining space, warehouses and toilets for employees and toilet for the disabled. The yard is used in summer, in the farmhouse, there is a storage space, meeting room and a bathroom Figure 6.

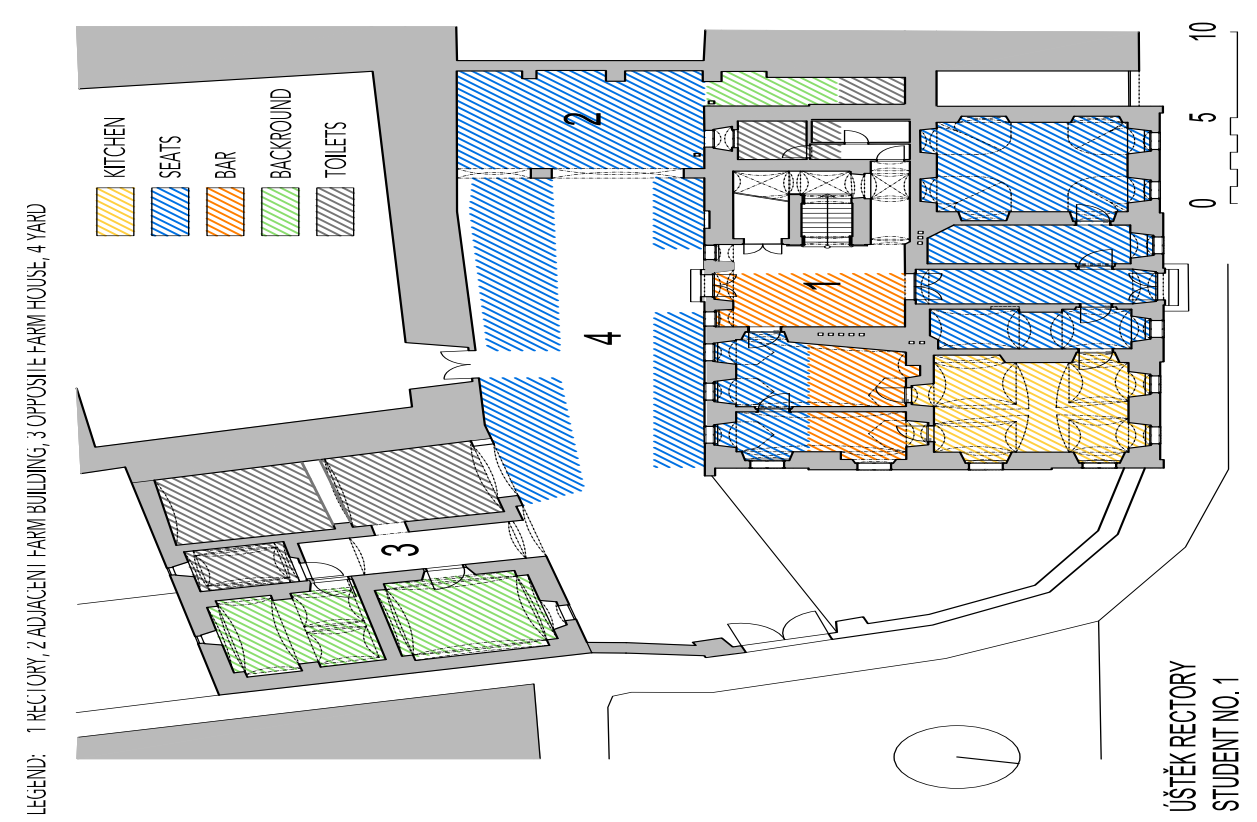

Fig. 1 - Layout of the building, Student No. 1 


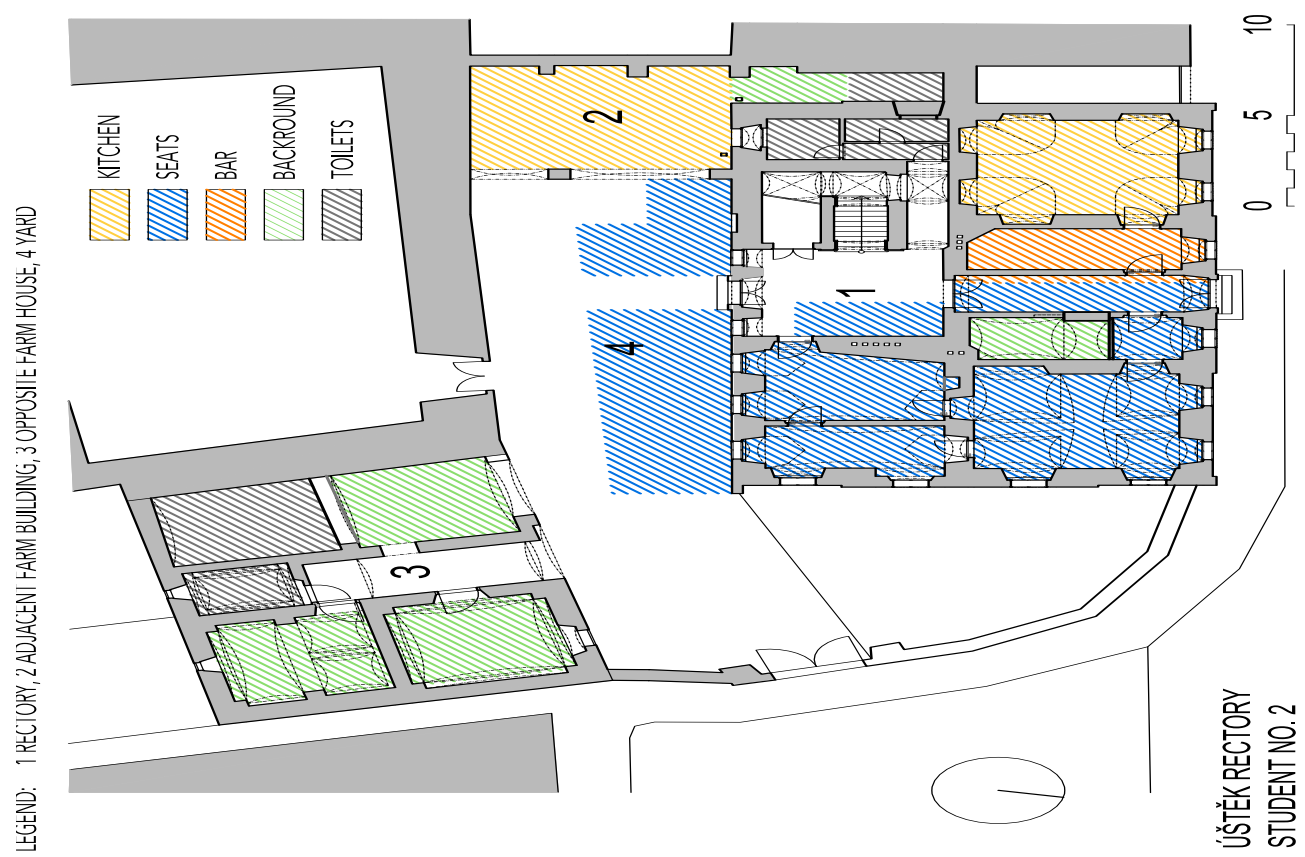

Fig. 2 - Layout of the building, Student No. 2

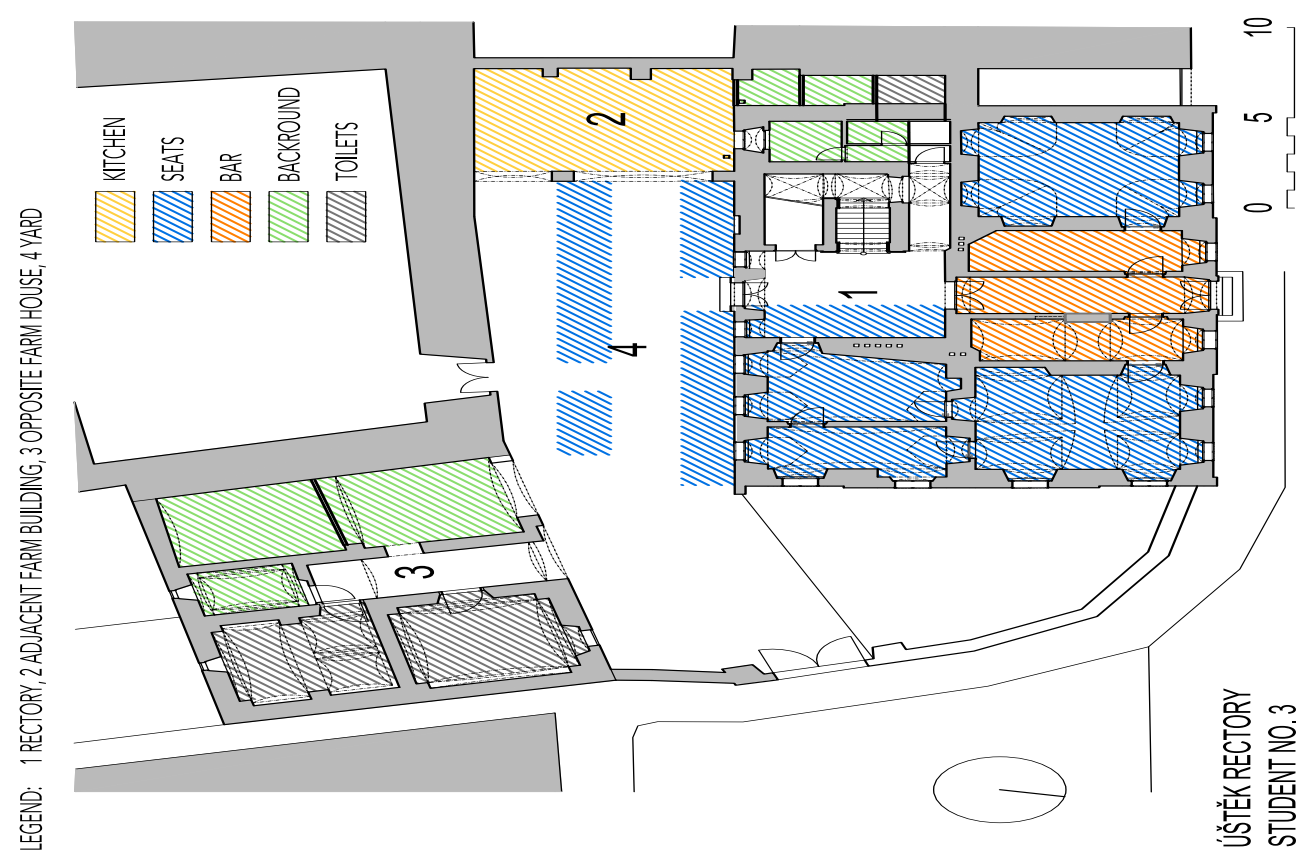

Fig. 3 - Layout of the building, Student No. 3 


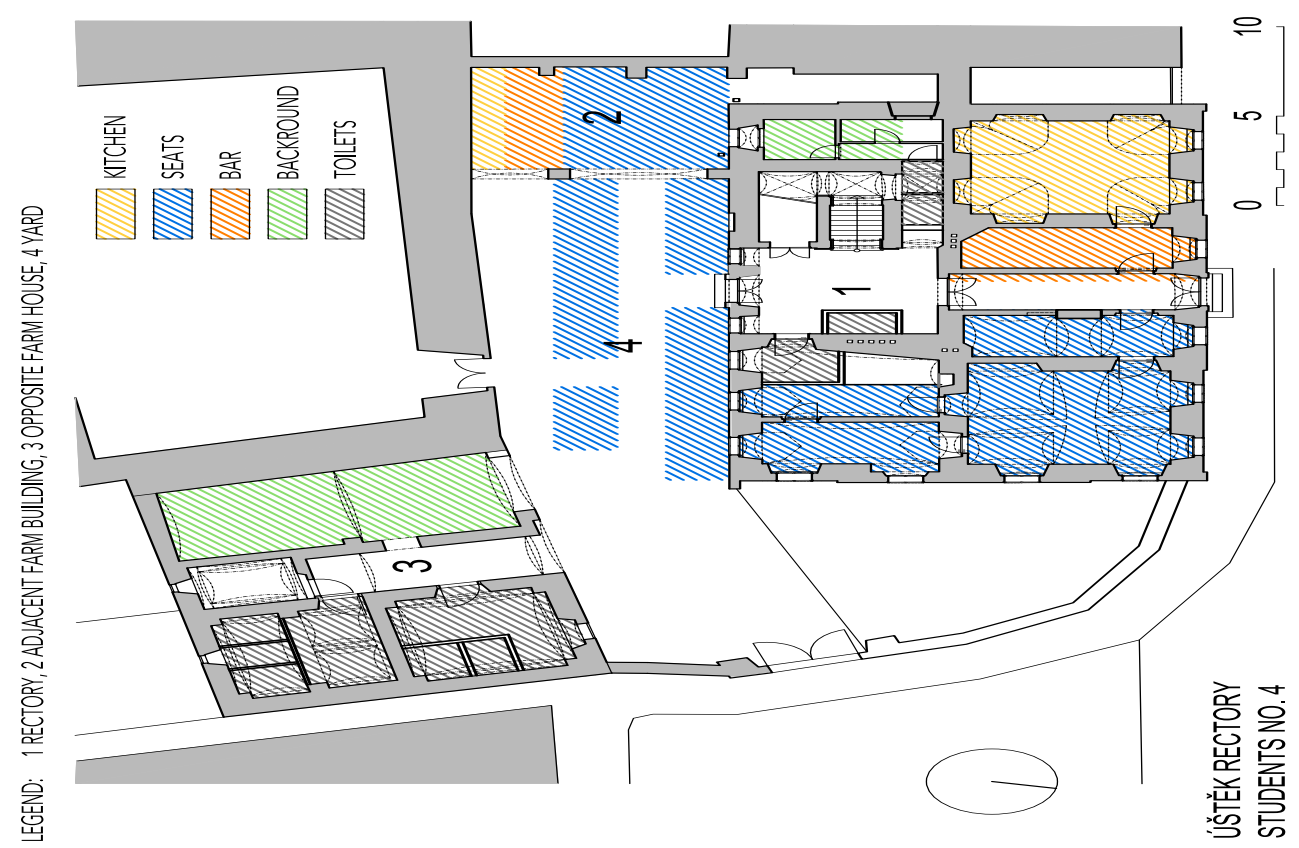

Fig. 4 - Layout of the building, Students No. 4

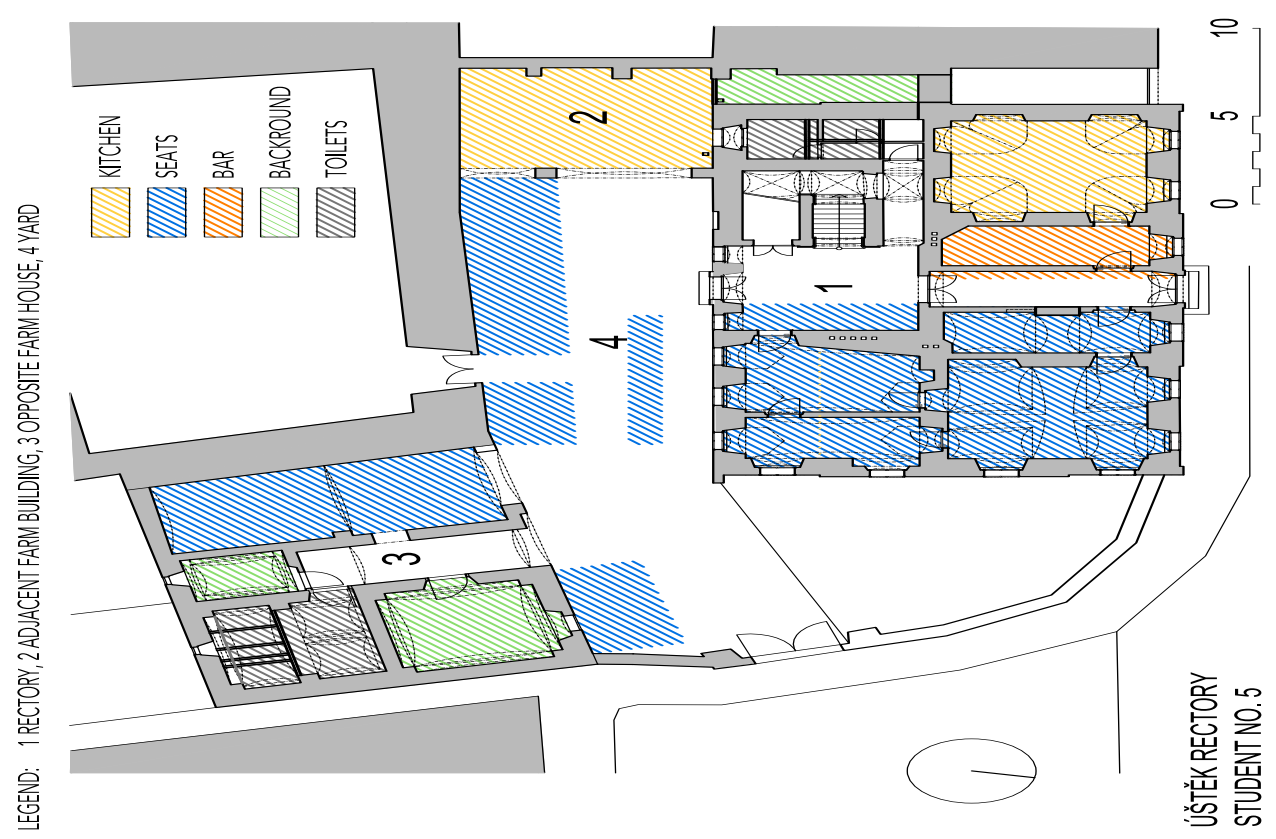

Fig. 5 - Layout of the building, Student No. 5 


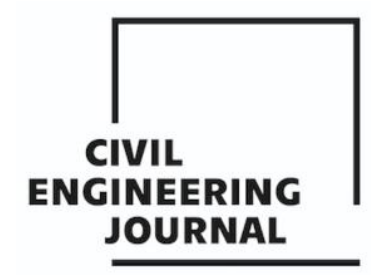

Article no. 45

THE CIVIL ENGINEERING JOURNAL 3-2021

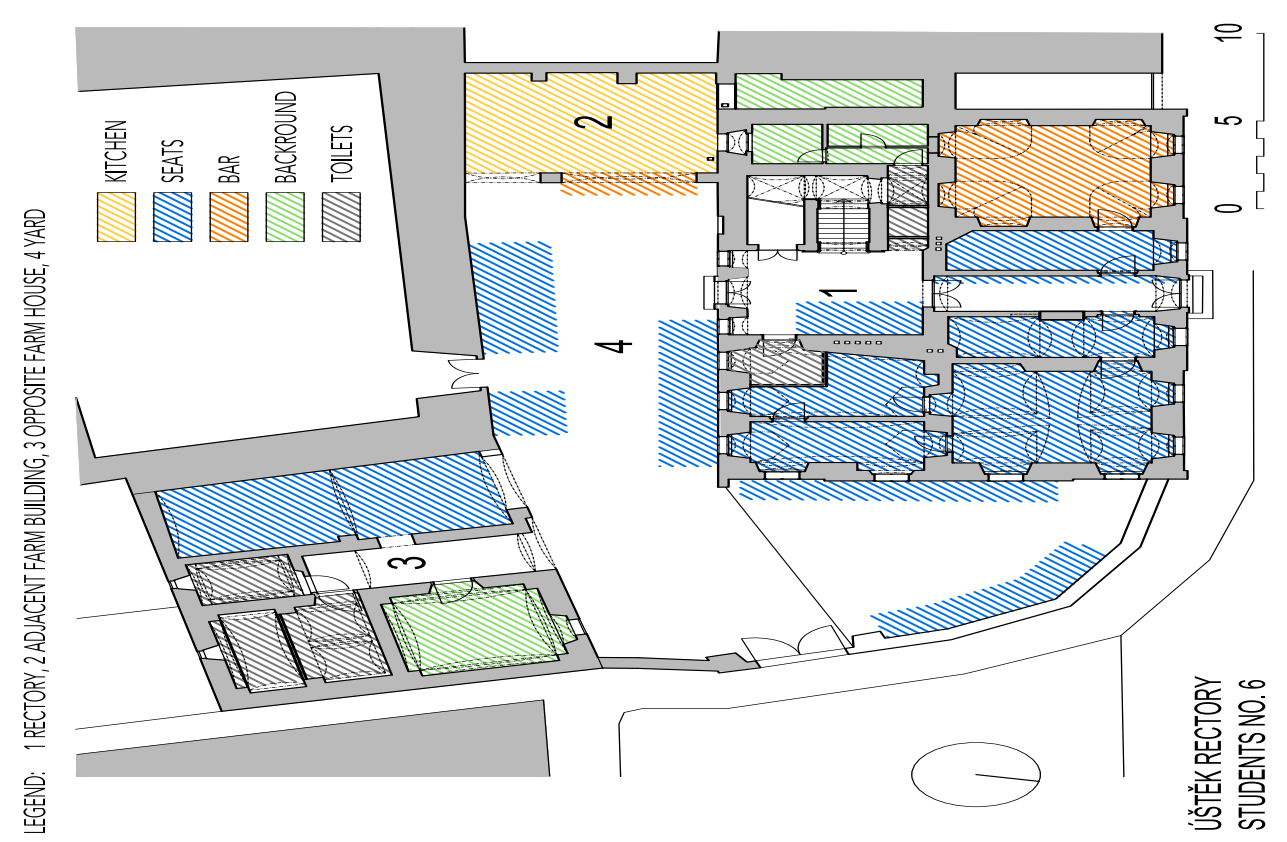

Fig. 6 - Layout of the building, Students No. 6

\section{ANALYSIS OF THE USE OF OBJECT AREAS}

\section{Total used area of the object}

Students had a different approach to the possible use of the object area. Individual projects vary in the way how the area is used also due to the different use of the seating area of the yard. Demolishing of constructions has a smallest influence on the differences in the using of the area. Most of the area used students No. 4, who used also a basement of the rectory and they also inhabited a first floor of the farm building. Other students covered to their plans only the area of the ground floors of all three buildings. It is interesting that the students who made biggest changes in the construction did not always use maximum of the space for the restaurant. The overall use of the area can be seen in the Figure 7.

\section{Demolished constructions}

The students intervened in the structures only to the necessary extent, taking into account that it was a listed building. Not all interventions were easy to make, however, the task was not limited by the budget. In the picture below, we can see highlighted constructions, that were demolished in all projects. Demolished structures were calculated in the area for simplified comparison. The areas of demolished constructions were between $6.27 \mathrm{~m}^{2}$ to $10.52 \mathrm{~m}^{2}$. Student No. 1 interfered the most to the constructions, student No. 3 changed the construction the least. Thanks to the sensitivity of the plans, individual proposes to demolition in the projects were not so big and in the area comparison they differ only slightly, see Figure 9. 
Article no. 45

CIVIL

THE CIVIL ENGINEERING JOURNAL 3-2021 JOURNAL

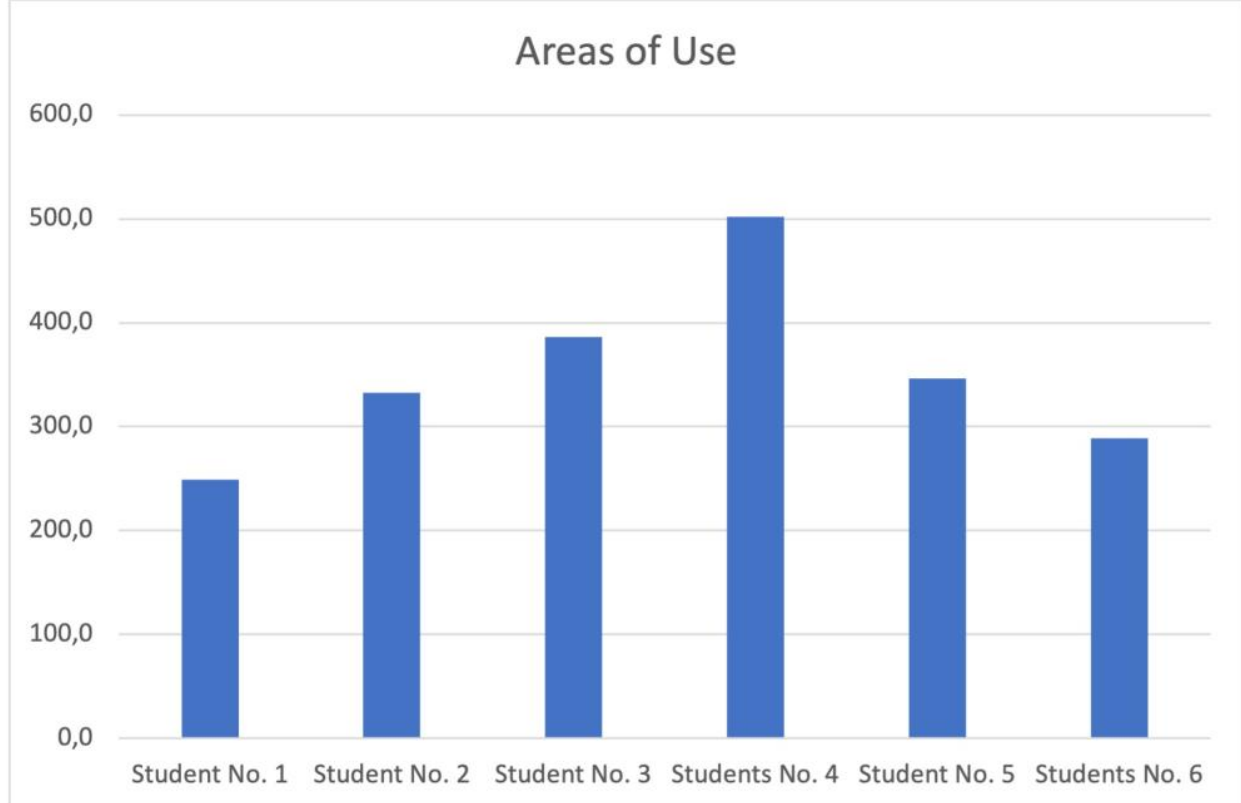

Fig. 7-Overall use of the area in square meters

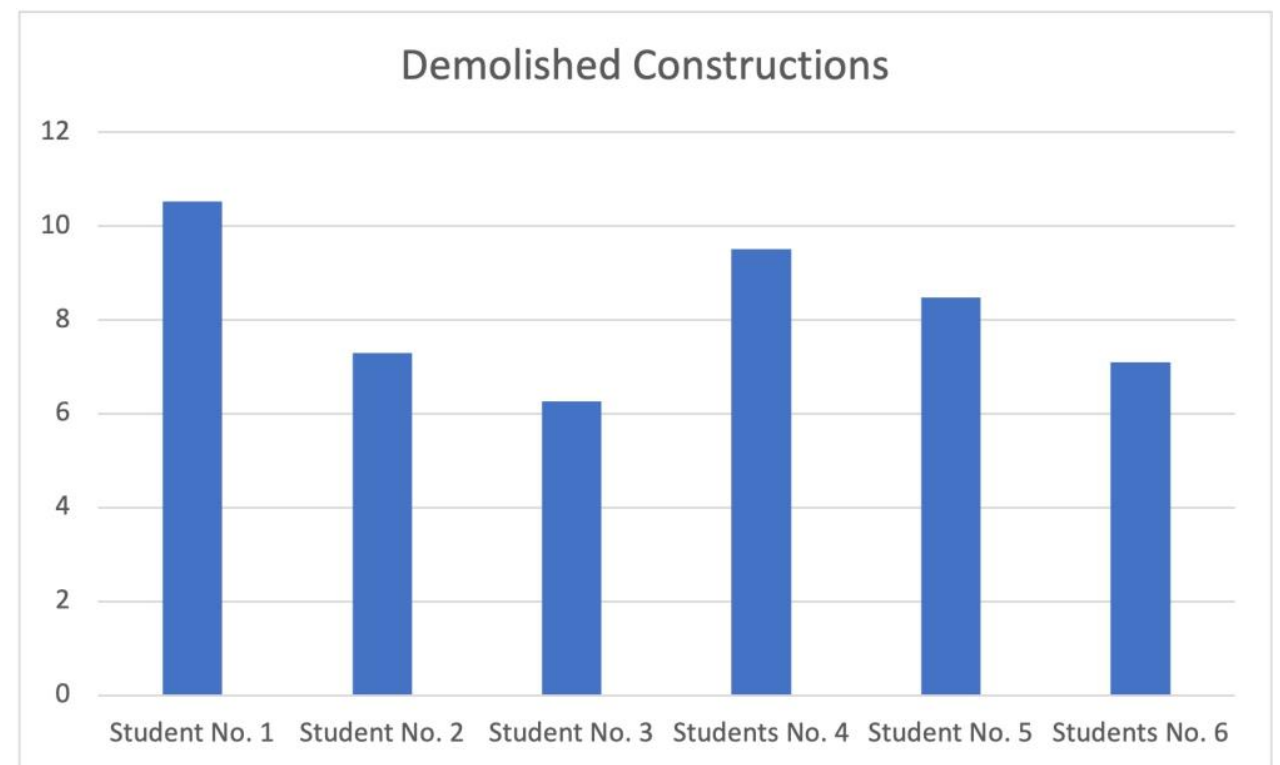

Fig. 8 - Overall demolished structures in $m^{2}$ 


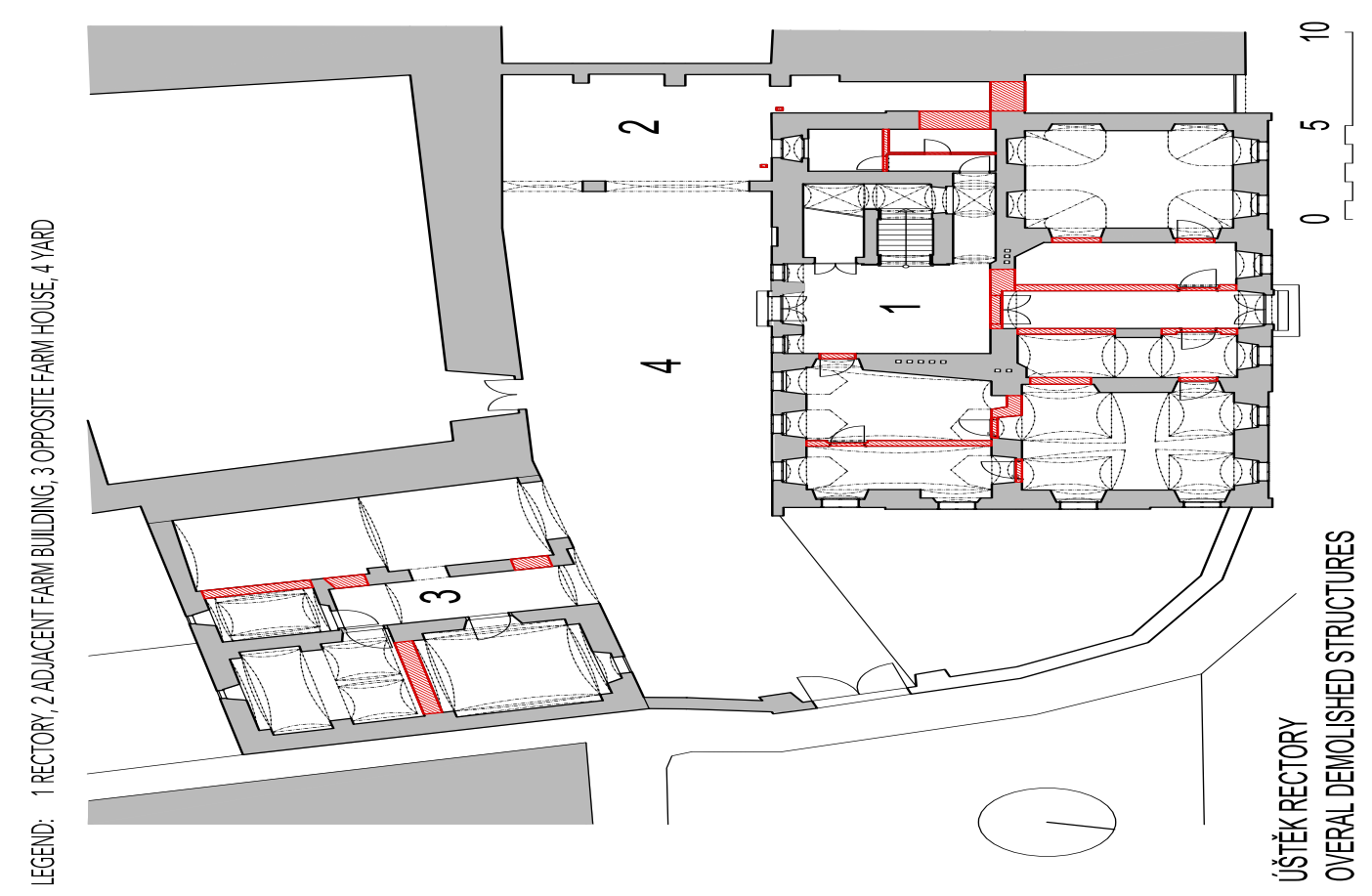

Fig. 9 - Graphical representation of the overall demolished structures

\section{Placement of the main operating parts of the restaurant}

\section{Kitchen placement}

The predominant agreement of student designs in the layout of the kitchen also examines the suitability of this placement. Student No. 1 located it in the southwest corner of the rectory. Student No. 2 designed a kitchen for the rectory in the room of the former chapel in the southeast corner and a summer kitchen in the outbuilding adjacent to the rectory. Student No. 3 situated the kitchen into the farmhouse adjacent to the rectory. Students No.4 placed the kitchen into the former chapel. Student No.5 designed the kitchens in the same way as student No. 2. Students 6 placed the kitchen to the farmhouse adjacent to the rectory, Figure 10. 


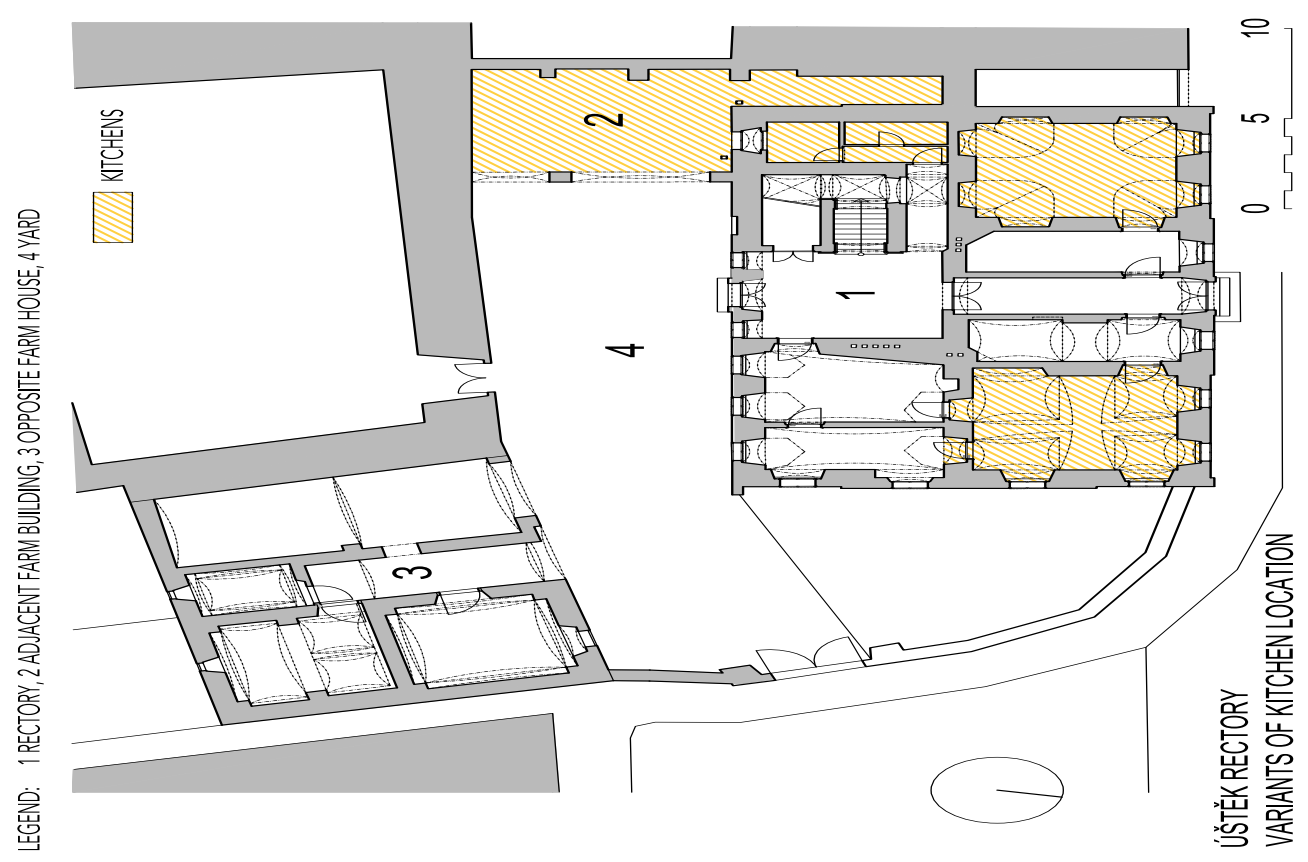

Fig. 10 - Floor plan with marked variants of kitchen location

\section{Bar placement}

Student No. 3 designed one bar that is in the central entrance room. Students No. 6 designed 2 bars, one in the former chapel and second is placed outside neighbouring with the outdoor kitchen situated in the farmhouse. Student No. 1 designed also 2 bars, one in the central part and second one - breakfast bar - in the north western part. Students No. 4 situated one bar to the central entrance part and second a summer bar to the farmhouse. Students No.2 and 5 situated the bar to the same place in the central entrance hall. Most of the students kept the demand of the conservationists not to place the bar to the former chapel. Only students No. 6 situated the bar bravely to the chapel. However, their design was very sensitive and referred to the original church use of the building, Figure 11. 


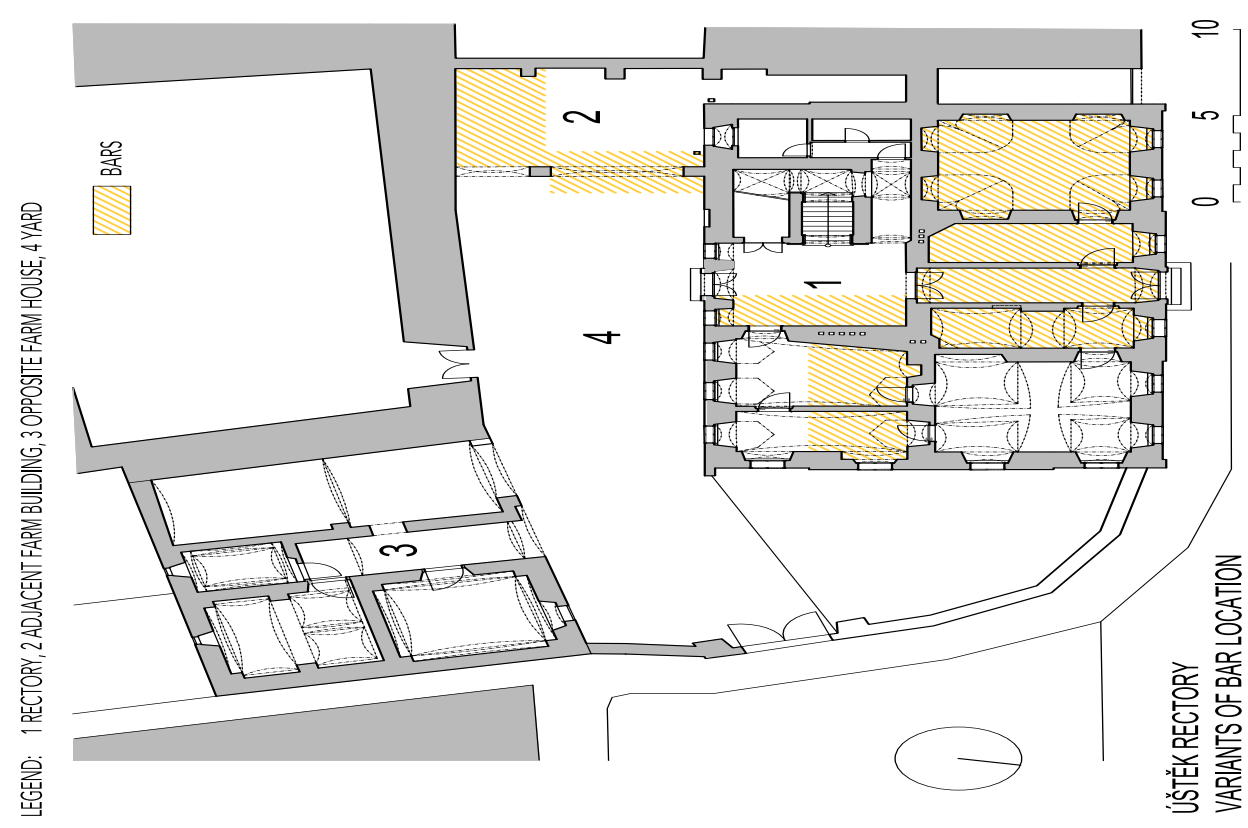

Fig. 11 - Floor plan with marked variants of bar location

\section{Areas of the rooms}

\section{Use of the area}

Due to the fact that the students used the space defined by the existing load-bearing masonry for the location of the kitchen, the students designed them in basically two sizes. The differences are only in the number of the kitchens in the individual plans, there is one kitchen or two. Second kitchen is always used for the summer terrace and therefore, it was placed in an outbuilding adjacent to the rectory.

Areas of the bars are different in individual projects because some students designed more than one bar. The bar areas do not include a separate bar-type seating, but only bar seating at staff bars.

Spaces used for the sitting of the guest are very different in single plans, student No. 1 used smallest space, the largest area is used by student No. 4. It is very interesting as both projects have similar size of the background.

Students No. 4 used the biggest area for the social facilities, the facilities are used also for the simple accommodation, which was designed in the attic of the farmhouse adjacent to the castle. Students have shown that the parish space is suitable for this form of use. A comparison of individual functional surfaces can be seen in Figure 13. 


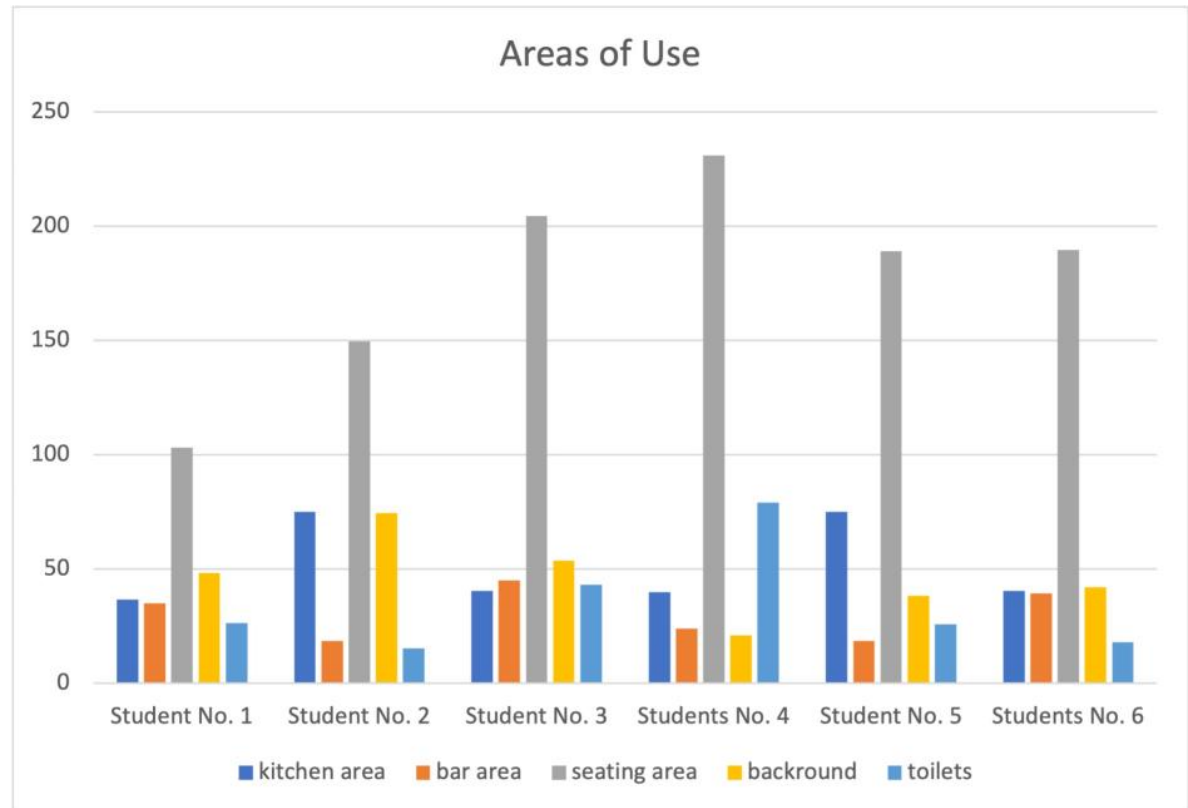

Fig. 12 - Resulting areas of use in $\mathrm{m}^{2}$ in individual student projects

\section{Number of seats}

Numbers of seats are divided into seats inside, bar seats and seats in the summer garden. To compare the number of places between individual projects, this distribution was not taken into account and the total number of places was correlated. The comparison of number of seats in terms of students' nationalities is interesting. Foreign students designed similar number of seats and similar number of sets was also in the projects of the Czech students. In total, foreign students proposed smaller number of seats than the Czech students. Student No. 1 has 89 seats, student No. 290 seats, student No. 3 only 78. Student No. 4 have 130 seats and even 8 beds of occasional sleeping. Student No. 5 has 111 seats and students No. 6 have 119 seats. The ratio of the proposed places can be seen in Figure 13.

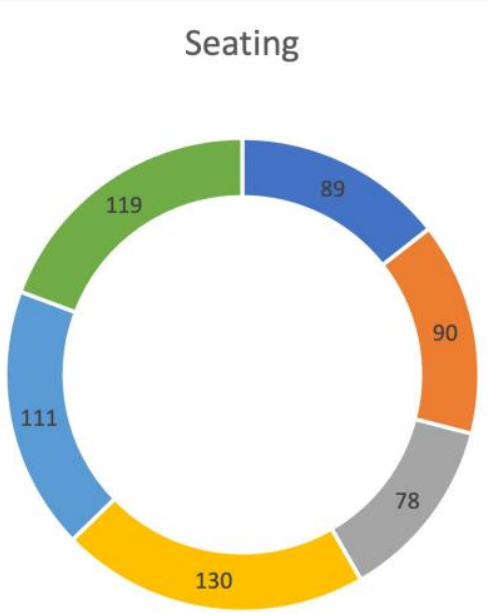

- Student No. 1 | Student No. 2 | Student No. 3 | Students No. 4 | Student No. 5 | Students No. 6

Fig. 13 - Number of seats in individual projects 


\section{CONCLUSION}

Students' works proved that a listed building of the rectory is suitable in terms of layout and capacity for the possible location of a restaurant with summer operation and a kitchen. Layout was solved in several possible plans. The objective of examining the possibility of operation has therefore been achieved.

Designs of interiors were various. Some inventively, imaginatively and exaggeratedly reflected the original use of the building, which they transferred to the newly designed interior projects. They followed up on the spiritual legacy of the original purpose of the building, even though the proposed content was problematic for the subjects of monument care, as they mainly assessed the ethical dimension of this use.

The use of church buildings as accommodation, restaurants, cafés is not unusual. Czech suitable examples can be Café Fara in Kletnice in South Moravia, Fara Hostinec in Loučná nad Desnou, residential restaurant in rectory in Kmetiněves or the almost historic Restaurant Na staré faře, in the original parish house near the church of St. Matěj in Prague 6.

The proposals were used as a basis for arguments during the meeting of the town hall management with the locally competent monument office. However, neither the intention of the city management nor the inspiring work of the students had any effect on the decision of the monument care. Their final opinion was the decision wording: "the operation of the restaurant would dishonour the building". The goal of positively influencing the decision of the locally competent authorities of monument care was therefore not achieved.

\section{REFERENCES}

[1] Farhanah N., Azhari N., Mohamed E., 2012. Public Perception: Heritage Building conservation in Kuala Lumpur. In: Proccedings of ASEAN Conference on Environment-Behaviour Studies, (Procedia - Social and Behavioral Sciences 50), 271 - 279, https://doi.org/10.1016/j.sbspro.2012.08.033

[2] Macdonald S., Cheong C., 2014. The Role of Public-Private Partnerships and the Third Sector in Conserving Heritage Buildings, Sites, and Historic Urban Areas (The Getty Conservation Institute, Los Angeles), http://hdl.handle.net/10020/gci pubs/public private partnerships

[3] Elsorady D.A., 2014. Assessment of the compatibility of new uses for heritage buildings: The example of Alexandria National Museum, Alexandria, Egypt, (Journal of Cultural Heritage, Volume 15, Issue 5) 511-521, https://doi.org/10.1016/j.culher.2013.10.011

[4] Haroun H.-A.A.F, Bakr A.F., Hasan A.E.-S., 2019. Multi-criteria decision making for adaptive reuse of heritage buildings: Aziza Fahmy Palace, Alexandria, Egypt (Alexandria Engineering Journal Volume 58, Issue 2) 467-478, https://doi.org/10.1016/i.aej.2019.04.003

[5] Langston C., Shen I.-Y., 2007. Application of the adaptive reuse potential model in Hong Kong: A case study of Lui Seng Chun (International Journal of Strategic Property Management, 11:4) 193-207, https://doi.org/10.1080/1648715X.2007.9637569

[6] Mehr S.Y., 2019. Analysis of 19th and 20th Century Conservation Key Theories in Relation to Contemporary Adaptive Reuse of Heritage Buildings (Heritage 2(1)) 920-937, https://doi.org/10.3390/heritage2010061

[7] Kelly C. 2012. Socialist Churches: Heritage Preservation and 'Cultic Buildings' in Leningrad, 19241940 (Slavic Review, vol. 71, no. 4, 2012) 792-823, https://doi.org/10.5612/slavicreview.71.4.0792

[8] DeBlock E., Fredericks A., Peacock D., Skrzek A., 2013. St. Mary's Parish House: Reuse and Rehabilitaion Feasibility Report (Historic Preservation. Paper 9.)

[9] Conejos S., Langston C., Smith J., 2011. Improving the implementation of adaptive reuse strategies for historic buildings (In The IX International Forum of Studies: S.A.V.E. Heritage Institute of Sustainable) 1$10 \mathrm{pp}$.

[10] Foster G., 2020, Circular economy strategies for adaptive reuse of cultural heritage buildings to reduce environmental impacts (Resources, Conservation and Recycling Volume 152), https://doi.org/10.1016/..resconrec.2019.104507

[11] Košt’ál B., 2015. Úštěk. (Baron, Hostivice)

[12] Gabriel, F., Kursová L., 2015. Město Úštěk a jeho dva hrady (Městský úřad, Úštěk) Kde se vzalo město Úštěk? 
Article no. 45

CIVIL

ENGINEERING

JOURNAL

THE CIVIL ENGINEERING JOURNAL 3-2021

[13] Kibic, K., 1981. Pamět' měst: městské památkové rezervace v Českých zemích, edited by Vladimíra Kašt'áková 2. vyd. (Odeon, Praha)

[14] Kuča, K. 2011. Města a městečka v Čechách, na Moravě a ve Slezsku (Praha, Libri) part 7

[15] Košt’ál B., Sassmanová H., 2011. Úštěk Městská památková rezervace (Úštěk, Louny) 